\title{
Impact of Periodontitis on Cardiovascular Diseases
}

\author{
Shashi Kant Agarwal
}

\section{ABSTRACT}

Cardiovascular diseases (CVDs) are the leading cause of global morbidity and mortality. Recently, an increasing amount of preventive and therapeutic scrutiny has been directed towards lifestyles and their effect on CVDs. Maintaining good dental health is a lifestyle behavior that can help prevent periodontitis (PD), tooth caries, and tooth loss. Published scientific data is persuasive that dental infections, such as PD, have significant deleterious effects on the cardiovascular system. This paper briefly reviews the association of PD with CVDs.

Keywords: Periodontitis, caries, tooth loss, cardiovascular disease.
Published Online: April 28, 2021

ISSN: 2684-4443

DOI: 10.24018 /ejdent.2021.2.2.48

Shashi Kant Agarwal*

Center for Contemporary and Complimentary Cardiology, USA. (e-mail: usacardiologist@ gmail.com)

*Corresponding Author

\section{INTRODUCTION}

It is estimated that periodontitis (PD) may affect $20 \%$ to $50 \%$ of the world population [1]. The oral cavity has more than 700 species of bacteria [2]. Some bacteria, such as Porphyromonas gingivalis (P. gingivalis), Aggregatibacter actinomycetemcomitans, Prevotella intermedia and spirochetes like Treponema denticola are pathogenic and cause infective PD [3]. P. gingivalis is the major invading pathogen in PD [4]. PD not only results in periodic bacteremia [5] but also causes systemic inflammatory changes [6], both of which may adversely affect distant organs and systems in the body [7]. Chronic ailments linked with PD include pulmonary diseases, diabetes mellitus, rheumatoid arthritis, and systemic lupus erythematosus [8]. PD can also affect pregnancy, with adverse outcomes [9]. According to the Global Burden of Diseases, from 1990 to 2017, oral diseases such as PD and caries, contributed the most years lost to disability for 354 diseases and injuries across 195 countries [10]. PD also has profound negative effects on the cardiovascular system, imparting significant morbidity and mortality [11]-[13].

\section{DISCUSSION}

Cardiovascular diseases (CVDs) include coronary artery disease (CAD), coronary heart disease (CHD) hypertension (HTN), stroke, CBVD, heart failure (HF), infective endocarditis (IF), cardiac arrhythmias including atrial fibrillation (AF), pericarditis, peripheral arterial disease (PAD), deep vein thrombosis (DVT) and vasculogenic erectile dysfunction (ED) [14], [15]. CVDs are the leading cause of morbidity and mortality in the world [16], [17].

Scientific meta-analytic studies have found a strong and consistent evidence that PD is associated with atherosclerosis [18] and an increased risk of future CVD events [19]. PD may also worsen pre-existing CVD [20] and treatment of PD appears to diminish CVD risk or its progression [21]. The mechanisms behind the increased risk of CVD in patients with PD are multiple [22]-[48]. Invasion of pathogenic bacteria into the gingival tissue leads to local inflammation [22]. The inflamed gingival tissues allow oral bacteria to enter the blood stream, resulting in bacteremia [23]. Bacteremia may result from daily activities such as toothbrushing or flossing, as well as following interventions such as tooth polishing, tooth extraction and periodontal probing [24, [25]. There bacteria invade the arterial wall and initiate or worsen atherosclerosis [26]. A meta-analysis of 63 studies (1791 patients) confirmed the presence of oral bacteria in atherosclerotic plaques [27]. PD increases the risk of developing atherosclerosis by 2.52 times [28]. Oral bacteria have also been detected in cardiac tissue, and in biopsies from heart valves [29]. Oral bacteria and/or their DNA have also been detected in pericardial fluid and vascular thrombi in many studies [30], [31]. An association has been demonstrated between elevated anti-P. gingivalis antibody levels and several CVDs [32]-[34]. PD also induces systemic inflammation [35] and this is evidenced by elevated systemic inflammation markers including IL-1 $\beta$, IL-8, IL-6 and tumour necrosis factor (TNF)- $\alpha$ [36]. Creactive protein (CRP) level, another marker of inflammation, is also increased in PD patients [37]. Swallowed P. gingivalis may also cause gut epithelial altherations that may increase inflammation [35]. The increased inflammation seen in these patients leads to endothelial dysfunction [38]. There is also an increase in reactive oxygen species in PD patients, which enhances the inactivation of nitric oxide and this further worsens endothelial dysfunction [39]. Additionally, PD is often associated with smoking and diabetes mellitus which also cause endothelial dysfunction [40]. Endothelial dysfunction is a major factor behind the development of atherosclerosis [41]. PD also affects the lipid profile, with an elevation in serum total cholesterol levels, low-density lipoproteins (LDL), triglycerides, very-low-density lipoproteins, 
oxidized LDL, and phospholipase A2 [42]. PD also reduces high-density lipoprotein levels (HDL) [42]. These lipid abnormalities further facilitate atherosclerosis [43]. PD patients have significantly higher levels of fibrinogen [44] and platelet activation markers [45], and both fibrinogen and aggregated platelets can induce thrombosis at the site of thin fibrous cap or fissure over a vulnerable lipid rich atherosclerotic lesion [46]. Genetic studies also indicate immunological commonalities between PD and CVDs [47], [48].

Regular dental hygiene and periodontal therapy helps reduce inflammatory markers [49], including CRP [50]. PD treatment also results in in a significant decrease in fibrinogen levels [51] and platelet activation markers [52]. The lipid profile also improves [53]. Clinically, self-performed oral hygiene habits, dental prophylaxis, regular dental care utilization and periodontal treatment helps reduce primary acute CVD events [54]-[57]. Periodontal treatment (including tooth extractions, nonsurgical and surgical periodontal therapy, and dental implant procedures) is generally safe in patients with CVD [58]. Individuals on single acetylsalicylic acid, clopidogrel, ticlopidine or ticagrelor therapy, do not have more bleeding events when compared to controls [59]. Dual antiplatelet therapy and anti-coagulants may increase bleeding, but usually this is manageable with local hemostatic measures [60], [61]. These medications are therefore not contraindicated for periodontal treatment and do not need to be discontinued. If doubt exists, and in patients with atrial fibrillation or with recent coronary stenting, consultation with the responsible medical professional is advisable [62], [63]. Further, antibiotic prophylaxis may be needed in certain cardiac patients with PD undergoing dental procedures to prevent infective endocarditis (IF) [64], [65].

\section{PERIODONTITIS AND HTN}

Several observational studies have recognized an association between moderate-severe PD and HTN [66]. A study of almost 12,000 dentate adults conducted by NHANES III found that in middle aged individuals, there was a linear relationship between systolic blood pressure (BP) and severe PD [67]. PD is a major cause of tooth loss in the adults [68] and adults with missing teeth have higher blood pressures [69]. A recent study using Mendelian randomization found a causal relationship between PD and HTN [70]. PD patients exhibit significant inflammation and endothelial dysfunction, factors that contribute towards the development of HTN [71]. HTN and PD also share several risk factors, such as, smoking, stress, increased age, and socioeconomic factors, and they also have an independent association [72]. HTN is a contributing factor in almost $50 \%$ of the deaths due to CVDs [73]. Law et al in a meta-analysis reported that a $10-\mathrm{mmHg}$ reduction in systolic and/or 5$\mathrm{mmHg}$ reduction in diastolic BP resulted in a $25-30 \%$ reduction of major cardiovascular events [74]. Czesnikiewicz-Guzik et al. found a reduction in BP of $7.5 \pm 10 \mathrm{mmHg}$ following intensive periodontal treatment [70].

\section{PERIODONTITIS AND CAD/CHD}

Dietrich and group, in a systemic review, found a robust association between PD and CAD/CHD [18]. Patients with PD have a higher rate of coronary artery events [75] and those with severe PD have the highest risk [76]. They also exhibit increased CHD mortality [77]. CAD is primarily due to atherosclerosis [78]. PD and atherosclerosis are strongly linked [79]. In a recent study of 72,630 patients with PD and a matched control group of 72,630 healthy patients, Tong and group found that male patients with chronic PD demonstrated a significantly higher risk of carotid atherosclerosis [80]. Carotid atherosclerosis is well known to be predictive of coronary atherosclerosis [81]. The latter can cause flow-limiting stenosis and plaque rupture, or an erosion can provoke atherothrombosis and vessel occlusion [82], leading to a myocardial infarction, or even death [83]. Besides endothelial dysfunction, inflammation and immune mediated responses, many other mechanisms are involved in the development and progression of atherosclerosis, including vascular lipid deposition [84]. Oral pathogens have been found in atherosclerotic plaques [85]. PD patients also exhibit harmful atheromatous plaque remodeling [86]. Plaque vulnerability may also be increased by PD related inflammation [87]. Oral bacteria such as Streptococcus sanguis are also known to increase platelet aggregation and increase the risk of thrombosis [88].

\section{PERIODONTITIS AND STROKE}

There is considerable evidence from epidemiologic studies that a direct association exists between PD and CVBD [89]. A systematic review by Dietrich et al, confirmed this association [18]. In the ARIC study, patients with PD had more than double the risk of cardioembolic and thrombotic stroke compared with periodontally healthy individuals [90]. The higher CVD mortality seen with PD is in part due to an increase in CBVD seen in these patients [18].

\section{Periodontitis ANd HeArt Failure}

PD and CHF frequently coexist [91]-[93]. Wood and Johnson noted that patients with PD tend to be at a higher CHF risk [91]. In a recent study, Aoyama and group found that enhanced antibody with high levels against $\mathrm{P}$ gingivalis were associated with a high prevalence with greater of heart failure [92]. PD is also affected by heart failure [93]. The prevalence and severity of PD is higher in CHF patients than in the age-adjusted general population, regardless of the cause of CHF [94]. Periodontal disease is present in $47.2 \%$ of the general population [95]. A periodontal disease rate of $76 \%$ was found by Lessem and group and a rate of $69 \%$ detected by Schulze-Spate and group, in HF patients [96, [97]. The relationship between $\mathrm{PD}$ and heart failure therefore appears to be bidirectional [92], [97]. PD and CHF share several common risk factors such as smoking, diabetes mellitus, HTN, CAD, excessive alcohol consumption, and low socioeconomic status [98]. However, PD also independently induces inflammation, and inflammation of the cardiac tissue is not uncommon in HF patients with PD 
[99]. Further, oral bacteria have also been noted in myocardial tissues [29].

\section{PERIODONTITIS AND ARRHYTHMIAS}

Holm-Pederson et al, using a multivariate logistic regression analysis, reported that persons with three or more active root caries lesions had more than twice the odds of cardiac arrhythmias than persons without active root caries [100]. PD is a major cause of dental caries [101]. A study involving 22 adult mongrel canines of both sexes demonstrated that PD is associated with an inflammatory response in the atrial myocardium, which facilitates the development of AF [102]. A study using the Taiwanese National Health Insurance Research Database found that individuals with PD had a significantly higher incidence of AF or atrial flutter compared with the non-PD group [103]. Further, in patients with atrial fibrillation, $\mathrm{PD}$ is an independent predictor of major adverse cardiovascular events [104]. Dental scaling, which reduces the risk of PD, lowers the risk of AF [105]. Besides inflammation, PD likely affects the pathogenesis of AF by many other pathways including oral bacteria directly invading the heart and their toxins affecting the myocardium and deleterious effects on the autonomic nervous system [106].

\section{Periodontitis AND VAlVUlar Diseases}

Dental infectious foci constitute a significant risk factor for infective endocarditis (IE) [107]. Bacteria from intradental foci have been found in the blood of $23.3 \%$ of patients with infective valvular endocarditis [107]. Bacteremia may occur after toothbrushing [108], and individuals with high levels of PD incur an almost eight-fold increased risk for bacteremia [109]. A recent study found fewer teeth and more advanced bone resorption in patients with IE, when compared to those without IE [110]. Further, preoperative periodontal treatment in patients undergoing cardiac valve surgery may help reduce postoperative infection [111].

\section{PERIODONTITIS AND PERICARDITIS}

PD may be associated with pericarditis [112]. In one study, $63.6 \%$ of pericarditis were positive for endodonticrelated bacteria and $36.4 \%$ were positive for PD-related bacteria in the pericardial fluid [112].

\section{Periodontitis And Congenital Heart Disease}

PD during pregnancy has been linked to miscarriage, preeclampsia, preterm birth, and low birthweight [113], [114]. Dental problems are common in individuals born with congenital heart disease (CoHD) [115]. CoHD patients, especially those with cyanotic conditions, often develop enamel anomalies [116] and these are probably related to chronic hypoxia induced enamel hypo-mineralization [117]. Enamel anomalies impart a higher risk of caries in these children [118]. Franco and group found a higher incidence of untreated caries (in primary dentition) in CoHD children when compared with other healthy children [116]. Untreated caries may often be a contra-indication for heart surgery, which these individuals often need [119]. PD may also increase the risk of IF endocarditis in patients with congenital cardiac defects [120].

\section{Periodontitis AND HeART Transplant}

Immunosuppressive drugs often used in heart transplant patients appear to increase the risk of gingival hyperplasia and periodontal conditions [121]. These patients often lead poor oral health-related behaviors such as infrequent toothbrushing and consumption of unhealthy snacks [122]. They may also not follow recommended professional dental evaluation, preventive interventions, and therapeutic care [123]. In a study of Chinese heart transplant patients, Cao and group reported poor periodontal health in heart transplant patients when compared with participants who had no such history [124]. Sezgin and Sezgin, in a more recent study, reported that when 40 heart transplant patients were compared with 40 healthy individuals, the former had higher mean probing depth, mean gingival recession, mean clinical attachment level, and mean plaque index scores on dental examination [122]. Poor oral health also further diminishes the quality of life in these patients [125].

\section{PERIODONTITIS AND PERIPHERAL ARTERY DiSEASE}

Mendez et al. noted that subjects with clinically significant PD at baseline had an increased risk of developing PAD [126]. Several subsequent studies have also noted a significant PD - PAD association [127]-[129]. Yang et al. did a meta-analysis of seven studies (total of 4307 participants) and confirmed a higher PAD risk in PD patients [129]. This increased risk is estimated to be fivefold [130]. Chen et al. also detected the presence of periodontopathic bacteria in $52 \%$ of the atherosclerotic specimens from patients with aorto-iliacal and femoropopliteal PAD [130]. PD is a major cause of tooth loss [68] and PAD patients have been noted to have fewer teeth than control subjects [131], [132].

\section{PERIODOnTITIS AND ERECTILE DYSFUnCTION}

ED is a multifactorial condition, and causes may be organic or psychological, or a combination of both [133]. Although vascular cause is the most common, in patients with PD it is usually a combination of vascular and psychological causes [134], [135]. Vasculogenic ED has been reported to have a higher incidence in PD patients in several studies [136]-[140]. A systemic review and metaanalysis by Liu and group confirmed a significant association between chronic PD and the risk of ED [141]. A more recent review of nine case-controlled studies and three meta-analysis further confirmed the significant association between these two conditions [142]. Wang et al, estimated that in patients with chronic PD, ED was increased approximately three-fold, when compared with non-PD controls [143]. Tooth lessness and oral mal odor related to $\mathrm{PD}$, have adverse emotional and social effects, which may 
also affect sexual performance [139], [144]. Further, these patients may suffer from poor nutrition, which may lead to systemic disorders, and further compromise socialization and sexual abilities [145]. PD treatment helps reduce erectile dysfunction [146].

\section{PERIODONTITIS AND VENOUS Thrombo-EMBOLISM}

$\mathrm{PD}$ is also associated with venous thromboembolism [147], [148]. Lippi et al found an increased risk of 1.9-fold of VTE in patients with severe PD when compared to those with no clinical signs of PD [148]. The increased risk climbed to 2.29-fold in patients who were edentulous [148]. In a prospective cohort study, using data from 8,092 participants in the Atherosclerosis Risk in Communities study to examine periodontal disease in 1996-1998 and incident VTE through 2011, Cowan et al found that selfreported tooth loss due to gum disease was associated with $30 \%$ higher VTE risk than no tooth loss due to gum disease, after elimination of confounding variables [149]. The major mechanism is systemic vascular inflammation [150]. Systemic inflammatory marker levels are effectively reduced by PD treatment, as reported in a meta-analysis of clinical trials [53].

\section{PERIODONTITIS AND OTHER CVD RISK FACTORS}

Diabetes mellitus is a major risk factor for CVD and PD has a proven relationship with insulin resistance and diabetes [151], [152]. PD is also associated with lipid abnormalities, such as high triglyceride levels and low HDL cholesterol levels [153]. Obesity, another risk factor for CVD, is also common in patients with PD [153]. Smoking, stress, chronic obstructive pulmonary disease, and chronic kidney disease are also related with PD and are also major risk factors for CVDs [154]-[157].

\section{CONCLUSION}

Self-reported PD is often under-reported. PD once detected, is frequently untreated. The adverse effects of PD on cardiac health are irrefutable. Several mechanisms are responsible, but systemic vascular inflammation appears to be the main driver. Diligent oral health care is of paramount importance in reducing future CVDs. Even one additional toothbrushing per day is associated with a reduction in CVD events, while a professional dental cleaning reduces this risk even further. Prompt treatment of periodontal therapy also imparts a positive impact upon cardiovascular health. PD should be considered as a modifiable risk factor for CVD.

\section{REFERENCES}

[1] Tonetti MS, Jepsen S, Jin L, Otomo-Corgel J. Impact of the global burden of periodontal diseases on health, nutrition and wellbeing of mankind: a call for global action. J Clin Periodontol 2017;44:456462.

[2] Paster BJ, Boches SK, Galvin JL, et al. Bacterial diversity in human subgingival plaque. Journal of Bacteriology. 2001;183(12):37703783 .

[3] Socransky SS, Haffajee AD. Dental biofilms: Difficult therapeutic targets. Periodontol 2000 2002; 28: 12-55.
[4] Hajishengallis G, Darveau RP, Curtis MA. The keystonepathogen hypothesis. Nat Rev Microbiol 2012; 10: 717-25.

[5] Tomás I, Diz P, Tobías A, Scully C, Donos N. Periodontal health status and bacteraemia from daily oral activities: systematic review/meta-analysis. J Clin Periodontol. 2012 Mar;39(3):213-28. doi: 10.1111/j.1600-051X.2011.01784.x.

[6] Pink C, Kocher T, Meisel P, Dorr M, Markus MR, Jablonowski L, et al. Longitudinal effects of systemic inflammation markers on periodontitis. Journal of clinical periodontology. 2015;42(11):988-97. 10.1111/jcpe. 12473 .

[7] Pizzo G, Guiglia R, Lo Russo L, Campisi G. Dentistry and internal medicine: from the focal infection theory to the periodontal medicine concept. Eur J Intern Med. 2010 Dec;21(6):496-502. doi: 10.1016/j.ejim.2010.07.011.

[8] Cardoso EM, Reis C, Manzanares-Cespedes MC. Chronic periodontitis, inflammatory cytokines, and interrelationship with other chronic diseases. Postgrad Med. 2018;130(1):98-104. doi: 10.1080/00325481.2018.1396876.

[9] Seymour GJ, Ford PJ, Cullinan MP, Leishman S, Yamazaki K. Relationship between periodontal infections and systemic disease. Clin Microbiol Infect. 2007;13(Suppl 4):3-10.

[10] G. B. D. Disease Injury and Incidence and Prevalence Collaborators (2018). Global, regional, and national incidence, prevalence, and years lived with disability for 354 diseases and injuries for 195 countries and territories, 1990-2017: A systematic analysis for the Global Burden of Disease Study 2017. Lancet, 392, 1789-1858. 10.1016/S0140-6736(18)32279-7.

[11] Pussinen PJ, Jousilahti P, Alfthan G, Palosuo T, Asikainen S, Salomaa V. Antibodies to periodontal pathogens are associated with coronary heart disease. Arterioscler Thromb Vasc Biol 2003; 23: $1250-4$.

[12] Hosomi N, Aoki S, Matsuo K, et al. Association of serum antiperiodontal pathogen antibody with ischemic stroke. Cerebrovasc Dis 2012; 34: 385-92.

[13] Sanz M, Marco Del Castillo A, Jepsen S, et al. Periodontitis and cardiovascular diseases: Consensus report. J Clin Periodontol. 2020;47(3):268-288. doi:10.1111/jcpe.13189.

[14] WHO About cardiovascular diseases. World Heal. Organ. 2018.

[15] https://www.who.int/cardiovascular_diseases/about_cvd/en/ accessed October 29, 2020.

[16] Yusuf S, Reddy S, Ounpuu S, et al. Global burden of cardiovascular diseases: part I: general considerations, the epidemiologic transition, risk factors, and impact of urbanization. Circulation 2001;104:274653. 10.1161/hc4601.099487.

[17] Chambless L, Keil U, Dobson A, et al. Population versus clinical view of case fatality from acute coronary heart disease: results from the WHO MONICA Project 1985-1990. Multinational MONItoring of Trends and Determinants in CArdiovascular Disease. Circulation 1997;96:3849-59. 10.1161/01.cir.96.11.3849.

[18] Dietrich T, Sharma P, Walter C, Weston P, Beck J. The epidemiological evidence behind the association between periodontitis and incident atherosclerotic cardiovascular disease. J

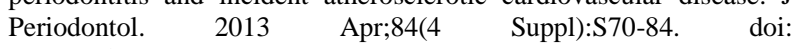
10.1902/jop.2013.134008.

[19] Van Dyke, TE, Kholy, KE, Ishai, A, et al. Inflammation of the periodontium associates with risk of future cardiovascular events. J Periodontol. 2021; 92: 348- 358. https://doi.org/10.1002/JPER.190441.

[20] Sen S, Sumner R, Hardin J, et al. Periodontal disease and recurrent vascular events in stroke/transient ischemic attack patients. Journal of Stroke and Cerebrovascular Diseases,2013, 22, 1420-1427. 10.1016/j.jstrokecerebrovasdis.2013.06.024.

[21] D'Aiuto, F., Orlandi, M., \& Gunsolley, J. C. (2013). Evidence that periodontal treatment improves biomarkers and CVD outcomes. Journal of Clinical Periodontology, 40(Suppl 14), S85-105. 10.1111/jcpe. 12061 .

[22] Fukui A., Ohta K., Nishi H., Shigeishi H., Tobiume K., Takechi M., Kamata N. Interleukin-8 and CXCL10 expression in oral keratinocytes and fibroblasts via Toll-like receptors. Microbiol. Immunol. 2013;57:198-206. doi: 10.1111/1348-0421.12022.

[23] Reyes L., Herrera D., Kozarov E., Roldá S., Progulske-Fox A. Periodontal bacterial invasion and infection: Contribution to atherosclerotic pathology. J. Periodontol. 2013;84:S30-S50. doi: 10.1902/jop.2013.1340012.

[24] Forner L., Larsen T., Kilian M., Holmstrup P. Incidence of bacteremia after chewing, tooth brushing and scaling in individuals with periodontal inflammation. J. Clin. Periodontol. 2006;33:401-407. doi: 10.1111/j.1600-051X.2006.00924.x.).

[25] Tomas, I., Diz, P., Tobias, A., Scully, C., \& Donos, N. (2012). Periodontal health status and bacteraemia from daily oral activities: 
Systematic review/meta-analysis. Journal of Clinical Periodontology, 39, 213-228. 10.1111/j.1600-051X.2011.01784.x.

[26] Nakano K., Inaba H., Nomura R., Nemoto H., Takeda M., Yoshioka H., Matsue H., Takahashi T., Taniguchi K., Amano A., et al. Detection of cariogenic Streptococcus mutans in extirpated heart valve and atheromatous plaque specimens. J. Clin. Microbiol. 2006;44:3313-3317. doi: 10.1128/JCM.00377-06.

[27] Chhibber-Goel J., Singhal V., Bhowmik D., Vivek R., Parakh N., Bhargava B., Sharma A. Linkages between oral commensal bacteria and atherosclerotic plaques in coronary artery disease patients. NPJ Biofilms Microbiomes. 2016;2:7. doi: 10.1038/s41522-016-0009-7.

[28] Beukers, N. G., van der Heijden, G. J., van Wijk, A. J., \& Loos, B. G. (2017). Periodontitis is an independent risk indicator for atherosclerotic cardiovascular diseases among 60174 participants in a large dental school in The Netherlands. Journal of Epidemiol Community Health, 71(1), 37-42. 10.1136/jech-2015-206745.

[29] Nakano K., Inaba H., Nomura R., Nemoto H., Takeda M., Yoshioka H., Matsue H., Takahashi T., Taniguchi K., Amano A., et al. Detection of cariogenic Streptococcus mutans in extirpated heart valve and atheromatous plaque specimens. J. Clin. Microbiol. 2006;44:3313-3317. doi: 10.1128/JCM.00377-06.

[30] Louhelainen A.M., Aho J., Tuomisto S., Aittoniemi J., Vuento R., Karhunen P.J., Pessi T. Oral bacterial DNA findings in pericardial fluid. J. Oral Microbiol. 2014;6:25835. doi: 10.3402/jom.v6.25835.

[31] Pessi T., Karhunen V., Karjalainen P.P., Ylitalo A., Airaksinen J.K., Niemi M., Pietila M., Lounatmaa K., Haapaniemi T., Lehtimäki T., et al. Bacterial signatures in thrombus aspirates of patients with myocardial infarction. Circulation. 2013;127:1219-1228. doi: 10.1161/CIRCULATIONAHA.112.001254

[32] Pussinen PJ, Alfthan G, Tuomilehto J, Asikainen S, Jousilahti P. High serum antibody levels to Porphyromonas gingivalis predict myocardial infarction. Eur J Cardiovasc Prev Rehabil 2004; 11: 40811.

[33] Taniguchi A, Nishimura F, Murayama Y, et al. Porphyromonas gingivalis infection is associated with carotid atherosclerosis in nonobese Japanese type 2 diabetic patients. Metabolism 2003; 52: 142-5.

[34] Hosomi N, Aoki S, Matsuo K, et al. Association of serum antiperiodontal pathogen antibody with ischemic stroke. Cerebrovasc Dis 2012; 34: 385-92.

[35] Hajishengallis G. Periodontitis: from microbial immune subversion to systemic inflammation. Nat Rev Immunol. 2015; 15: 30- 44.

[36] Pink C, Kocher T, Meisel P, Dorr M, Markus MR, Jablonowski L, et al. Longitudinal effects of systemic inflammation markers on periodontitis. Journal of clinical periodontology. 2015;42(11):988-97. $10.1111 /$ jcpe. 12473 .

[37] Ling, M. R., Chapple, I. L., \& Matthews, J. B. (2016). Neutrophil superoxide release and plasma C-reactive protein levels pre- and post-periodontal therapy. Journal of Clinical Periodontology, 43, 652658. 10.1111/jcpe.12575.

[38] Kirby M, Jackson G, Simonsen U. Endothelial dysfunction links erectile dysfunction to heart disease. Int J Clin Pract. 2005;59:225-9.

[39] Zuo Z, Jiang J, Jiang R, Chen F, Liu J, Yang H, et al. Effect of periodontitis on erectile function and its possible mechanism. J Sex Med. 2011;8:2598-605.

[40] Gimbrone MA., Jr Vascular endothelium: An integrator of pathophysiologic stimuli in atherosclerosis. Am J Cardiol. 1995;75:67-70B.

[41] Mudau M, Genis A, Lochner A, Strijdom H. Endothelial dysfunction: the early predictor of atherosclerosis. Cardiovasc J Afr. 2012 May;23(4):222-31. doi: 10.5830/CVJA-2011-068.

[42] Schenkein HA, Loos BG. Inflammatory mechanisms linking periodontal diseases to cardiovascular diseases. Journal of Clinical Periodontology. 2013; 40(Suppl 14): S51-69. DOI: https://doi.org/10.1111/jcpe.12060.

[43] Choy PC, Siow YL, Mymin D, O K. Lipids and atherosclerosis. Biochem Cell Biol. 2004 Feb;82(1):212-24. doi: 10.1139/o03-085.

[44] Chandy, S., Joseph, K., Sankaranarayanan, A., Issac, A., Babu, G., Wilson, B., \& Joseph, J. (2017). Evaluation of C-reactive protein and fibrinogen in patients with chronic and aggressive periodontitis: A clinico-biochemical study. Journal of Clinical and Diagnostic Research, 11, Zc41-zc45 10.7860/jcdr/2017/23100.9552.

[45] Arvanitidis, E., Bizzarro, S., Alvarez Rodriguez, E., Loos, B. G., \& $\mathrm{Nicu}$, E. A. (2017). Reduced platelet hyper-reactivity and platelet-leukocyte aggregation after periodontal therapy. Thrombosis Journal, 15, 5 10.1186/s12959-016-0125-x.

[46] Tatsumi K, Mackman N. Tissue Factor and Atherothrombosis. J Atheroscler Thromb. 2015;22(6):543-9. doi: 10.5551/jat.30940. Epub 2015 May 27.

[47] 47. Aarabi, G., Zeller, T., Seedorf, H., Reissmann, D. R., Heydecke, G., Schaefer, A. S., \& Seedorf, U. (2017). Genetic susceptibility contributing to periodontal and cardiovascular disease. Journal of Dental Research, 96, 610-617. 10.1177/0022034517699786.

[48] Munz, M., Richter, G. M., Loos, B. G., Jepsen, S., Divaris, K., Offenbacher, S., Schaefer, A. S. (2018). Genome-wide association meta-analysis of coronary artery disease and periodontitis reveals a novel shared risk locus. Scientific Reports, 8, 13678 10.1038/s41598018-31980-8.

[49] D'Aiuto F, Parkar M, Andreou G, Suvan J, Brett PM, Ready D, et al. Periodontitis and systemic inflammation: control of the local infection is associated with a reduction in serum inflammatory markers. Journal of dental research. 2004;83(2):156-60.

[50] Ling, M. R., Chapple, I. L., \& Matthews, J. B. (2016). Neutrophil superoxide release and plasma C-reactive protein levels pre- and post-periodontal therapy. Journal of Clinical Periodontology, 43, 652658. 10.1111/jcpe. 12575.

[51] Vidal, F., Cordovil, I., Figueredo, C. M., \& Fischer, R. G. (2013). Non-surgical periodontal treatment reduces cardiovascular risk in refractory hypertensive patients: A pilot study. Journal of Clinical Periodontology, 40, 681-687. 10.1111/jcpe.12110.

[52] Arvanitidis, E., Bizzarro, S., Alvarez Rodriguez, E., Loos, B. G., \& Nicu, E. A. (2017). Reduced platelet hyper-reactivity and platelet-leukocyte aggregation after periodontal therapy. Thrombosis Journal, 15, 5 10.1186/s12959-016-0125-x.

[53] Teeuw, W. J., Slot, D. E., Susanto, H., Gerdes, V. E., Abbas, F., D'Aiuto, F., Loos, B. G. (2014). Treatment of periodontitis improves the atherosclerotic profile: A systematic review and meta-analysis. Journal of Clinical Periodontology, 41, 70-79. 10.1111/jcpe.12171.

[54] Park SY, Kim SH, Kang SH, Yoon CH, Lee HJ, Yun PY, Youn TJ, Chae IH. Improved oral hygiene care attenuates the cardiovascular risk of oral health disease: A population-based study from Korea. European Heart Journal. 2019; 40: 1138-1145. DOI: 10.1093/eurheartj/ehy836.

[55] Lee, Y. L., Hu, H. Y., Chou, P., \& Chu, D. (2015). Dental prophylaxis decreases the risk of acute myocardial infarction: A nationwide population-based study in Taiwan. Clinical Interventions in Aging, 10, 175-182. 10.2147/CIA.S67854.

[56] Sen S, Giamberardino LD, Moss K, Morelli T, Rosamond WD, Gottesman RF, Beck J, Offenbacher S. Periodontal Disease, Regular Dental Care Use, and Incident Ischemic Stroke. Stroke. 2018; 49: 355-362. DOI: https://doi.org/10.1161/STROKEAHA.117.018990/

[57] Holmlund, A., Lampa, E., \& Lind, L. (2017). Poor response to periodontal treatment may predict future cardiovascular disease. Journal of Dental Research, 96, 768-773. 10.1177/0022034517701901

[58] Sanz M, Marco Del Castillo A, Jepsen S, et al. Periodontitis and cardiovascular diseases: Consensus report. J Clin Periodontol. 2020 Mar;47(3):268-288. doi: 10.1111/jcpe.13189.

[59] Doganay, O., Atalay, B., Karadag, E., Aga, U., \& Tugrul, M. Bleeding frequency of patients taking ticagrelor, aspirin, clopidogrel, and dual antiplatelet therapy after tooth extraction and minor oral surgery. Journal of the American Dental Association, 2018, 149, 132 138. 10.1016/j.adaj.2017.09.052.

[60] Nathwani, S., \& Martin, K. Exodontia in dual antiplatelet therapy: The evidence. British Dental Journal, 2016. 220, 235-238. 10.1038/sj.bdj.2016.173.

[61] Shi, Q., Xu, J., Zhang, T., Zhang, B., \& Liu, H. (2017). Post-operative bleeding risk in dental surgery for patients on oral anticoagulant therapy: A meta-analysis of observational studies. Frontiers in Pharmacology, 8, 58 10.3389/fphar.2017.00058.

[62] Kwak, E. J., Nam, S., Park, K. M., Kim, S. Y., Huh, J., \& Park, W. (2019). Bleeding related to dental treatment in patients taking novel oral anticoagulants (NOACs): A retrospective study. Clinical Oral Investigations, 23, 477-484. 10.1007/s00784-018-2458-2.

[63] Steffel, J., Verhamme, P., Potpara, T. S., Albaladejo, P., Antz, M., Desteghe, L. ESC Scientific Document Group (2018b). The 2018 European Heart Rhythm Association Practical Guide on the use of non-vitamin $\mathrm{K}$ antagonist oral anticoagulants in patients with atrial fibrillation. European Heart Journal, 39, 1330-1393. 10.1093/eurheartj/ehy136.

[64] https://www.heart.org/en/health-topics/infective-endocarditis accessed March 31, 2021.

[65] https://www.escardio.org/Guidelines/Clinical-PracticeGuidelines/Infective-Endocarditis-Guidelines-on-PreventionDiagnosis-and-Treatment-of - accessed March 31, 2021.

[66] Eva Muñoz Aguilera, Jean Suvan, Jacopo Buti, Marta CzesnikiewiczGuzik, et al. Periodontitis is associated with hypertension: a systematic review and meta-analysis, Cardiovascular Research, Volume 116, Issue 1, 1 January 2020, Pages 28-39, https://doi.org/10.1093/cvr/cvz201. 
[67] Tsakos G, Sabbah W, Hingorani ADetal. Is periodontal inflammation associated with raised blood pressure Evidence from a National US survey. J Hypertens. 2010;28:2386-93.

[68] Ong G. Periodontal disease and tooth loss. Int Dent J, 1998. 48(3 Suppl 1), 233-238.

[69] Völzke H, Schwahn C, Dörr M, et al. Gender differences in the relation between number of teeth and systolic blood pressure. J Hypertens. 2006;24:1257-63.

[70] Czesnikiewicz-Guzik M, Osmenda G, Siedlinski M, et al. Causal association between periodontitis and hypertension: evidence from Mendelian randomization and a randomized controlled trial of nonsurgical periodontal therapy. Eur Heart J. 2019 Nov 1;40(42):3459 3470. doi: 10.1093/eurheartj/ehz646.

[71] Tonetti MS, D'Aiuto F, Nibali L, Donald A, Storry C, Parkar M, Suvan J, Hingorani AD, Vallance P, Deanfield J. Treatment of periodontitis and endothelial function. N Engl J Med 2007;356:911920.

[72] Lockhart PB, Bolger AF, Papapanou PN, et al. Periodontal disease and atherosclerotic vascular disease: does the evidence support an independent association? A scientific statement from the american heart association. Circulation. 2012;125(20):2520-2544.

[73] Bronner LL, Kanter DS, Manson JE. Primary prevention of stroke. N Engl J Med. 1995;333:1392-400.

[74] Law MR, Morris JK, Wald NJ. Use of blood pressure lowering drugs in the prevention of cardiovascular disease: meta-analysis of 147 randomised trials in the context of expectations from prospective epidemiological studies. BMJ 2009;338:b1665.

[75] Rydén L, Buhlin K, Ekstrand E, et al. Periodontitis Increases the Risk of a First Myocardial Infarction: A Report From the PAROKRANK Study. Circulation. 2016 Feb 9;133(6):576-83. doi: 10.1161/CIRCULATIONAHA.115.020324.

[76] Gomes-Filho IS, Coelho JMF, Miranda SS, et al, Severe and moderate periodontitis are associated with acute myocardial infarction. J Periodontol. 2020 Nov;91(11):1444-1452. doi: 10.1002/JPER.19-0703.

[77] Romandini M, Baima G, Antonoglou G, Bueno J, Figuero E, Sanz M. Periodontitis, Edentulism, and Risk of Mortality: A Systematic Review with Meta-analyses. J Dent Res. 2021 Jan;100(1):37-49. doi: $10.1177 / 0022034520952401$.

[78] Ala-Korpela M. The culprit is the carrier, not the loads: cholesterol, triglycerides and apolipoprotein $\mathrm{B}$ in atherosclerosis and coronary heart disease. Int J Epidemiol. 2019 Oct 1;48(5):1389-1392. doi 10.1093/ije/dyz068.

[79] Pinho MM, Faria-Almeida R, Azevedo E, Manso MC, Martins L. Periodontitis and atherosclerosis: an observational study. J Periodontal Res. 2013 Aug;48(4):452-7. doi: 10.1111/jre.12026;

[80] Tong C, Wang YH, Chang YC. Increased Risk of Carotid Atherosclerosis in Male Patients with Chronic Periodontitis: A Nationwide Population-Based Retrospective Cohort Study. Int J Environ Res Public Health. 2019;16(15):2635. Published 2019 Jul 24 doi:10.3390/ijerph16152635.

[81] Jeevarethinam A, Venuraju S, Weymouth M, Atwal S, Lahiri A. Carotid intimal thickness and plaque predict prevalence and severity of coronary atherosclerosis: a pilot study. Angiology. 2015 Jan;66(1):65-9. doi: 10.1177/0003319714522849.

[82] Crea F, Libby P. Acute coronary syndromes: the way forward from mechanisms to precision treatment. Circulation. 2017;136:1155-1166.

[83] Bentzon JF, Otsuka F, Virmani R, Falk E. Mechanisms of plaque formation and rupture. Circ Res. 2014 Jun 6;114(12):1852-66. doi: 10.1161/CIRCRESAHA.114.302721.

[84] Schenkein H.A., Loos B.G. Inflammatory mechanisms linking periodontal diseases to cardiovascular diseases. J. Periodontol. 2013;1:S51-S69. doi: 10.1902/jop.2013.134006.

[85] Haraszthy VI, Zambon JJ, Trevisan M, Zeid M, Genco RJ. Identification of periodontal pathogens in atheromatous plaques. J Periodontol. 2000;71(10):1554-60.

[86] de Boer, S. P., Cheng, J. M., Range, H., et al. Antibodies to periodontal pathogens are associated with coronary plaque remodeling but not with vulnerability or burden. Atherosclerosis, 2014:237, 84-91. 10.1016/j.atherosclerosis.2014.08.050.

[87] Tabas I, Bornfeldt KE. Macrophage Phenotype and Function in Different Stages of Atherosclerosis. Circ Res. 2016 Feb 19;118(4):653-67. doi: 10.1161/CIRCRESAHA.115.306256.

[88] Papapanagiotou D, Nicu EA, Bizzarro S, et al. Periodontitis is associated with platelet activation. Atherosclerosis. 2009; 202: 605611.

[89] Sfyroeras GS, Roussas N, Saleptsis VG, Argyriou C, Giannoukas AD. Association between periodontal disease and stroke. J Vasc Surg. 2012 Apr;55(4):1178-84. doi: 10.1016/j.jvs.2011.10.008.
[90] Sen, S., Giamberardino, L. D., Moss, K., et al. Periodontal disease, regular dental care use, and incident ischemic stroke. Stroke, 2018:49, 355-362. 10.1161/STROKEAHA.117.018990.

[91] Wood N, Johnson RB. The relationship between tomato intake and congestive heart failure risk in periodontitis subjects. J Clin Periodontol. 2004 Jul;31(7):574-80. doi: 10.1111/j.1600051X.2004.00531.x.

[92] Aoyama N, Kure K, Minabe M, Izumi Y. Increased Heart Failure Prevalence in Patients with a High Antibody Level Against Periodontal Pathogen. Int Heart J. 2019 Sep 27;60(5):1142-1146. doi: 10.1536/ihj.19-010.

[93] Cekici A, Kantarci A, Hasturk H, Van Dyke TE. Inflammatory and immune pathways in the pathogenesis of periodontal disease Periodontol 2000. 2014; 64: 57-80.

[94] Fröhlich H, Herrmann K, Franke J, et al. Periodontitis in Chronic Heart Failure. Tex Heart Inst J. 2016 Aug 1;43(4):297-304. doi: 10.14503/THIJ-15-5200.

[95] Eke PI, Dye BA, Wei L, Thornton-Evans GO, Genco RJ; CDC Periodontal Disease Surveillance workgroup: James Beck, Gordon Douglass, Roy Page. Prevalence of periodontitis in adults in the United States: 2009 and 2010. J Dent Res. 2012 Oct;91(10):914-20. doi: $10.1177 / 0022034512457373$.

[96] Lessem J, Drisko C, Greenwell H, et al. Are cardiac transplant patients more likely to have periodontitis? A case record study. J Int Acad Periodontol. 2002 Jul;4(3):95-100.

[97] Schulze-Späte U, Mizani I, Salaverry KR, et al. Periodontitis and bone metabolism in patients with advanced heart failure and after heart transplantation. ESC Heart Fail. 2017 May;4(2):169-177. doi 10.1002/ehf2.12126.

[98] Reynolds MA. Modifiable risk factors in periodontitis: at the intersection of aging and disease. Periodontol 2000. 2014;64(1):7-19.

[99] Hofmann U, Frantz S. How can we cure a heart "in flame"? A translational view on inflammation in heart failure. Basic Res Cardiol. 2013;108(4):356.

[100]Holm-Pedersen P, Avlund K, Morse DE, Stoltze K, Katz RV Viitanen $\mathrm{M}$, et al. Dental caries, periodontal disease, and cardiac arrhythmias in community-dwelling older persons aged 80 and older: is there a link? Journal of the American Geriatrics Society. 2005;53(3):430-7. 10.1111/j.1532-5415.2005.53160.x.

[101]AlQobaly L, Sabbah W. The association between periodontal disease and root/coronal caries. Int J Dent Hyg. 2020 Feb;18(1):99-106. doi: 10.1111/idh.12422.

[102] Yu G, Yu Y, Li YN, Shu R. Effect of periodontitis on susceptibility to atrial fibrillation in an animal model. Journal of electrocardiology. 2010;43(4):359-66. 10.1016/j.jelectrocard.2009.12.002.

[103]Chen DY, Lin CH, Chen YM, Chen HH. Risk of Atrial Fibrillation or Flutter Associated with Periodontitis: A Nationwide, PopulationBased, Cohort Study. PLoS One. 2016 Oct 31;11(10):e0165601. doi: 10.1371/journal.pone.0165601.

[104] Im SI, Heo J, Kim BJ, et al. Impact of periodontitis as representative of chronic inflammation on long-term clinical outcomes in patients with atrial fibrillation. Open Heart. 2018 Apr 25;5(1):e000708. doi: 10.1136/openhrt-2017-000708.

[105]Chen SJ, Liu CJ, Chao TF, Wang KL, Chen TJ, Chou P, et al. Dental scaling and atrial fibrillation: a nationwide cohort study. International journal of cardiology. 2013;168(3):2300-3 10.1016/j.ijcard.2013.01.192.

[106] Aarabi G, Schnabel RB, Heydecke G, Seedorf U. Potential Impact of Oral Inflammations on Cardiac Functions and Atrial Fibrillation Biomolecules. 2018 Aug 1;8(3):66. doi: 10.3390/biom8030066.

[107]Wisniewska-Spychala B, Sokalski J, Grajek S, et al. Dentigenous infectious foci - a risk factor of infective endocarditis. Med Sci Monit. 2012 Feb;18(2):CR93-104. doi: 10.12659/msm.882464

[108]Lockhart P.B., Brennan M.T., Sasser H.C., Fox P.C., Paster B.J. Bahrani-Mougeot F.K. Bacteremia associated with toothbrushing and dental extraction. Circulation. 2008;117:3118-3125. doi 10.1161/CIRCULATIONAHA.107.758524.

[109]Lockhart P.B., Brennan M.T., Thornhill M., Michalowicz B.S., Noll J., Bahrani-Mougeot F.K., Sasser H.C. Poor oral hygiene as a risk factor for infective endocarditis-related bacteremia. J. Am. Dent. Assoc. 2009;140:1238-1244. doi: 10.14219/jada.archive.2009.0046

[110]Ninomiya M, Hashimoto M, Yamanouchi K, Fukumura Y, Nagata T, Naruishi K. Relationship of oral conditions to the incidence of infective endocarditis in periodontitis patients with valvular heart disease: a cross-sectional study. Clin Oral Investig. 2020 Feb;24(2):833-840. doi: 10.1007/s00784-019-02973-2.

[111] Suzuki H, Matsuo K, Okamoto M, Nakata H, Sakamoto H, Fujita M Preoperative periodontal treatment and its effects on postoperative infection in cardiac valve surgery. Clin Exp Dent Res. $2019 \mathrm{Jul}$ 10;5(5):485-490. doi: 10.1002/cre2.212. 
[112]Louhelainen A.M., Aho J., Tuomisto S., Aittoniemi J., Vuento R., Karhunen P.J., Pessi T. Oral bacterial DNA findings in pericardial fluid. J. Oral Microbiol. 2014;6:25835. doi: 10.3402/jom.v6.25835.

[113] McCormick MC. The contribution of low birth weight to infant mortality and childhood morbidity. N Engl J Med 1985;312:82-90.; Shennan AH. Recent developments in obstetrics. BMJ 2003;327:60418.

[114] Mathew RJ, Bose A, Prasad JH, Muliyil JP, Singh D. Materna periodontal disease as a significant risk factor for low birth weight in pregnant women attending a secondary care hospital in South India: a case-control study. Indian J Dent Res. 2014 Nov-Dec;25(6):742-7. doi: 10.4103/0970-9290.152184

[115] Tasioula V, Balmer R, Parsons J. Dental health and treatment in a group of children with congenital heart disease. Pediatr Dent 2008;30:323-8

[116]Franco F, Saunders CP, Roberts GJ, Suwanprasit A. Dental disease, caries related microflora and salivary IgA of children with severe congenital cardiac disease: an epidemiological and oral microbial survey. Pediatr Dent 1996;18:228-35.

[117]Jalevik B, Noren JG. Enamel hypomineralization of permanent first molars: A morphological study and survey of possible aetiological factors. Int J Paediatr Dent 2000;10:278-89.

[118] Hallett KB, Radford DJ, Seow WK. Oral health of children with congenital cardiac diseases: a controlled study. Pediatr Dent 1992;14:224-30.

[119]Hayes PA, Fasules J. Dental screening of pediatric cardiac surgical patients, J Dent Child 2001; 68:255-58.

[120]Folwaczny M, Bauer F, Grünberg C. Significance of oral health in adult patients with congenital heart disease. Cardiovasc Diagn Ther. 2019;9(Suppl 2):S377-S387. doi:10.21037/cdt.2018.09.17.

[121]Gruter MO, Brand HS. Oral health complications after a heart transplant: a review. Br Dent J. 2020 Feb;228(3):177-182. doi: 10.1038/s41415-020-1244-0.

[122] Salyer J, Flattery MP, Joyner PL, et al. Lifestyle and quality of life in long-term cardiac transplant recipients. J Heart Lung Transplant 2003;22:309-21.

[123] Sezgin Y, Sezgin A. Periodontal status and dental behaviour of heart transplant recipients and healthy controls. Acta Odontol Scand. 2020 Jan;78(1):20-25. doi: 10.1080/00016357.2019.1683889.

[124]Cao Y, Chen X, Jia Y, Lv Y, Sun Z. Oral health status of adult heart transplant recipients in China: A cross-sectional study. Medicine (Baltimore). 2018 Sep;97(38):e12508. doi: 10.1097/MD.0000000000012508.

[125] Schmalz G, Eisner M, Binner C, et al. Oral health-related quality of life of patients after heart transplantation and those with heart failure is associated with general health-related quality of life: a crosssectional study. Qual Life Res. 2020;29(6):1621-1630. doi:10.1007/s11136-020-02439-z.

[126] Mendez MV, Scott T, LaMorte W, Vokonas P, Menzoian JO, Garcia R. An association between periodontal disease and peripheral vascular disease. Am J Surg. 1998;176(2):153-157. doi: 10.1016/S00029610(98)00158-5.

[127] Soto-Barreras U, Olvera-Rubio JO, Loyola-Rodriguez JP, ReyesMacias JF, Martinez-Martinez RE, Patino-Marin N, et al. Peripheral arterial disease associated with caries and periodontal disease. J Periodontol. 2013;84(4):486-494. doi: 10.1902/jop.2012.120051.

[128]Lu, B, Parker, D, \& Eaton CB. Relationship of periodontal attachment loss to peripheral vascular disease: An analysis of NHANES 19992002 data. Atherosclerosis, 2018:200, 199-205. 10.1016/j.atherosclerosis.2007.12.037.

[129] Yang S, Zhao LS, Cai C, Shi Q, Wen N, Xu J. Association between periodontitis and peripheral artery disease: a systematic review and meta-analysis. BMC Cardiovasc Disord. 2018 Jul 6;18(1):141. doi: 10.1186/s12872-018-0879-0.

[130]Chen YW, Umeda M, Nagasawa T, Takeuchi Y, Huang Y, Inoue Y, Iwai T, Izumi Y, Ishikawa I. Periodontitis may increase the risk of peripheral arterial disease. Eur J Vasc Endovasc Surg. 2008 Feb;35(2):153-8. doi: 10.1016/j.ejvs.2007.08.016.

[131] Aoyama N, Suzuki JI, Kobayashi N, Hanatani T, Ashigaki N, Yoshida A, et al. Periodontitis deteriorates peripheral arterial disease in Japanese population via enhanced systemic inflammation. Heart Vessel. 2017;32(11):1314-1319. doi: 10.1007/s00380-017-1003-6.

[132] Yang S, Zhao LS, Cai C, Shi Q, Wen N, Xu J. Association between periodontitis and peripheral artery disease: a systematic review and meta-analysis. BMC Cardiovasc Disord. 2018 Jul 6;18(1):141. doi: 10.1186/s12872-018-0879-0.

[133] Heidelbaugh JJ. Management of erectile dysfunction. Am Fam Physician. 2010;81:305-12.
[134] Sharma A, Pradeep AR, Raju PA. Association between chronic periodontitis and vasculogenic erectile dysfunction. J Periodontol. 2011;82:1665-9.

[135] Uppal RS, Bhandari R, Singh K. Association between erectile dysfunction and chronic periodontitis: A clinical study. Indian J Den Res 2014;25:430.

[136]Zadik Y, Bechor R, Galor S, Justo D, Heruti RJ. Erectile dysfunction might be associated with chronic periodontal disease: Two ends of the cardiovascular spectrum. J Sex Med. 2009;6:1111-6.

[137] Oguz F, Eltas A, Beytur A, Akdemir E, Uslu MO, Günes A. Is there a relationship between chronic periodontitis and erectile dysfunction? J Sex Med. 2013;10:838-43.

[138] Matsumoto S, Matsuda M, Takekawa M, Okada M, Hashizume K, Wada N, et al. Association of ED with chronic periodontal disease. Int J Impot Res. 2013;26:13-5.

[139]Uppal RS, Bhandari R, Singh K. Association between erectile dysfunction and chronic periodontitis: A clinical study. Indian J Dent Res. 2014;25:430.

[140]Chou MH, Tsao CW, Cha TL, Wu ST, Liu CY. Chronic periodontitis as risk indicator of erectile dysfunction in young population. Int $\mathrm{J}$ Urol. 2016;23(Suppl 1):1-142.

[141]Liu LH, Li EM, Zhong SL, et al. Chronic periodontitis and the risk of erectile dysfunction: a systematic review and meta-analysis. Int J Impot Res. 2017 Jan;29(1):43-48. doi: 10.1038/ijir.2016.43.

[142]Bizzarro S, Loos BG. The link between periodontitis and erectile dysfunction: a review. Br Dent J. 2019 Oct;227(7):599-603. doi: 10.1038/s41415-019-0724-6

[143] Wang Q, Kang J, Cai X, Wu Y, Zhao L. The association between chronic periodontitis and vasculogenic erectile dysfunction: A systematic review and metaanalysis. J Clin Periodontol 2016;43:20615.

[144] Singh VP, Nettemu SK, Nettem S, Hosadurga R, Nayak SU. Oral Health and Erectile Dysfunction. J Hum Reprod Sci. 2017 JulSep;10(3):162-166. doi: 10.4103/jhrs.JHRS_87_17.

[145]Montague D.K. Jarow J.P. Broderick G.A. et al. Chapter 1: the management of erectile dysfunction: an AUA update. J Urol. 2005; 174: 230-239.

[146]Eltas A, Oguz F, Uslu MO, Akdemir E. The effect of periodontal treatment in improving erectile dysfunction: A randomized controlled trial. J Clin Periodontol. 2013;40:148-54.

[147] Sanchez-Siles M, Rosa-Salazar V, Camacho-Alonso F, SalazarSanchez N, \& Cozar-Hidalgo J (2013). Association between periodontal disease and venous thromboembolic disease Quintessence Int, 44(8), 567-573. doi:10.3290/j.qi.a29749.

[148]Lippi G, Nocini R, Favaloro EJ. Periodontal Disease and Venous Thromboembolism. Semin Thromb Hemost. 2021 Feb;47(1):110-111. doi: 10.1055/s-0040-1714399.

[149] Cowan LT, Lakshminarayan K, Lutsey PL, Folsom AR, Beck J, Offenbacher S, Pankow JS. Periodontal disease and incident venous thromboembolism: The Atherosclerosis Risk in Communities study. J Clin Periodontol. 2019 Jan;46(1):12-19. doi: 10.1111/jcpe.13029.

[150]Folsom AR, Lutsey PL, Astor BC, \& Cushman M (2009). C-reactive protein and venous thromboembolism. A prospective investigation in the ARIC cohort. Thromb Haemost, 102(4), 615-619. doi:10.1160/TH09-04-0274.

[151] Grossi SG, Genco RJ. Periodontal disease and diabetes mellitus: a two-way relationship. Ann Periodontol. 1998;3:51-61.

[152]Benguigui C, Bongard V, Ruidavets JB, Chamontin B, Sixou M, Ferrières $\mathrm{J}$, Amar $\mathrm{J}$. Metabolic syndrome, insulin resistance, and periodontitis: a cross-sectional study in a middle-aged French population. J Clin Periodontol. 2010 Jul;37(7):601-8. doi: 10.1111/j.1600-051X.2010.01571.x.

[153] Teixeira FCF, Marin-Leon L, Gomes EP, PedrÃo AMN, Pereira ADC, Francisco PMSB. Relationship between periodontitis and subclinical risk indicators for chronic non-communicable diseases. Braz Oral Res. 2020 Jun 19;34:e058. doi: 10.1590/1807-3107bor2020.vol34.0058.

[154] Gautam, D. K., Jindal, V., Gupta, S. C., Tuli, A., Kotwal, B., \& Thakur, R. (2011). Effect of cigarette smoking on the periodontal health status: A comparative, cross sectional study. Journal of Indian Society of Periodontology, 15(4), 383-387. 10.4103/0972 124x.92575

[155]Fenol, A., Jebi, S., Krishnan, S., Perayil, J., Vyloppillil, R., Bhaskar A., XXX, \& Mohandas, Ashitha. (2017). Association of stress, salivary cortisol level, and periodontitis among the inmates of a central prison in Kerala. Dental Research Journal (Isfahan), 14(4), 288-292. 10.4103/1735-3327.211625.

[156]Linden, G. J., Lyons, A., \& Scannapieco, F. A. (2013). Periodontal systemic associations: Review of the evidence. Journal of Clinica Periodontology, 40(Suppl 14), S8-19. 10.1111/jcpe.12064. 
[157]Sharma, P., Dietrich, T., Ferro, C. J., Cockwell, P., \& Chapple, I. L.

(2016). Association between periodontitis and mortality in stages 3-5 chronic kidney disease: NHANES III and linked mortality study. Journal of Clinical Periodontology, 43, 104-113. 10.1111/jcpe.12502. 